\title{
Multiple immunological abnormalities in patients with Type 1 (insulin-dependent) diabetes mellitus
}

\author{
D. W. Drell* and A. L. Notkins \\ Laboratory of Oral Medicine, National Institute of Dental Research, National Institutes of Health, Bethesda, Maryland, USA
}

Destruction of the insulin-secreting B cells of the pancreas is responsible for Type 1 (insulin-dependent) diabetes mellitus. A variety of factors including viruses, chemicals and immune reactions mediated by cells or antibodies have been implicated as possible causes of this destruction [1-10]. Over the last few years it has become clear that autoimmune abnormalities are associated with the majority of cases of Type 1 diabetes mellitus. Whether these autoimmune abnormalities are the exclusive cause, a contributing factor, the result, or simply a marker for pancreatic B-cell damage is still not absolutely clear. What triggers the autoimmune response also is not known.

In this review, we summarize the evidence showing that Type 1 diabetes mellitus is characterized by not only an autoimmune response to pancreatic B cells, but also by a variety of other immunological abnormalities; that some of these abnormalities are transient; and that perturbations in the regulation of insulin secretion may affect immune responsiveness. Where possible, we have presented the data in a quantitative or semiquantitative form so that the state of knowledge could be better evaluated. For purposes of comparison, some of the data from original articles were put in a different format and recalculated.

\section{Multiple autoantibodies}

The most commonly reported immunological abnormality in Type 1 diabetes mellitus is autoantibodies reacting with pancreatic islet-cell antigens [reviewed in $2,6,11-13]$. These antibodies have been divided into two types, one reacting with cytoplasmic antigens (ICA) and the other reacting with surface antigens (ICSA). In general, ICA are detected by indirect immunofluorescence on frozen sections of human pancreas, whereas ICSA are detected on viable cells using direct cytotoxicity $[14,15]$, immunofluorescence [16] or radioimmu-

\footnotetext{
* Current address: Laboratory of Virus and Cancer Research, Department of Medicine, George Washington University Medical Center, Washington, D.C., USA
}

noassay [17]. In patients with recently diagnosed Type 1 diabetes ICA are found in over $60 \%$ of cases [11-13, 18-20], while in non-diabetic control subjects ICA are found in $0.5-2 \%$ [19-24] of cases. Recent reports indicate that ICA can be detected in some individuals months or even years prior to the onset of clinical symptoms of diabetes, suggesting that Type 1 diabetes may have a longer and more chronic course than previously thought, and that ICA may be a marker for detecting Type 1 diabetes [25-28].

What is perhaps not as fully appreciated is that, in addition to islet cell antibodies, a variety of other autoantibodies are elevated in patients with Type 1 diabetes mellitus. Moreover, the frequency of other autoimmune diseases is higher in diabetic patients than in the normal population [29-31]. Some of the autoantibodies found in Type 1 diabetes are listed in Table $1[14,19,20-24$, 32-71], along with reported frequencies in both Type 1 diabetic patients and control subjects. For some of the autoantibodies the data base is not large, whereas for others it is quite extensive. In some cases data were pooled from several studies to calculate an overall percentage. In addition to autoantibodies to islet cells, autoantibodies to insulin and insulin receptors are found in Type 1 diabetic patients but rarely in non-diabetic subjects. Similarly, autoantibodies to a variety of nonpancreatic antigens are found in patients with Type 1 diabetes. For example, more Type 1 patients as compared to control subjects have autoantibodies to B lymphocytes $(19.1 \%$ vs. $4.3 \%)$, gastric parietal cells $(11.1 \%$ vs. $5.8 \%)$, thyroid microsomal antigens $(17.9 \%$ vs. $5.8 \%)$, thyroglobulin ( $10 \%$ vs. $4.4 \%)$, anterior pituitary ( $19.7 \%$ vs. $0 \%)$ and nuclear antigens $(9.9 \%$ vs. $1.6 \%)[21,45-56$, $58,60,61,64,65]$. Three studies on autoantibodies to adrenal gland antigens have appeared, one [43] to adrenal medulla and two $[52,56]$ to adrenal cortex. All report a higher frequency in Type 1 diabetic patients than in control subjects both for autoantibodies to adrenal medulla ( $39.5 \%$ vs. $0.7 \%$ ) and autoantibodies to adrenal cortex ( $1.9 \%$ vs. $0.5 \%)$. Wide divergences in frequencies have been reported for autoantibodies to isletcell surface antigens (36\% to $65 \%$ ), insulin ( $20 \%$ to $69 \%$ ) and pancreatic A cells (1\% to $37 \%)[14,19,34,36,38,43$, 
Table 1. Autoantibodies in patients with Type 1 diabetes mellitus and control subjects

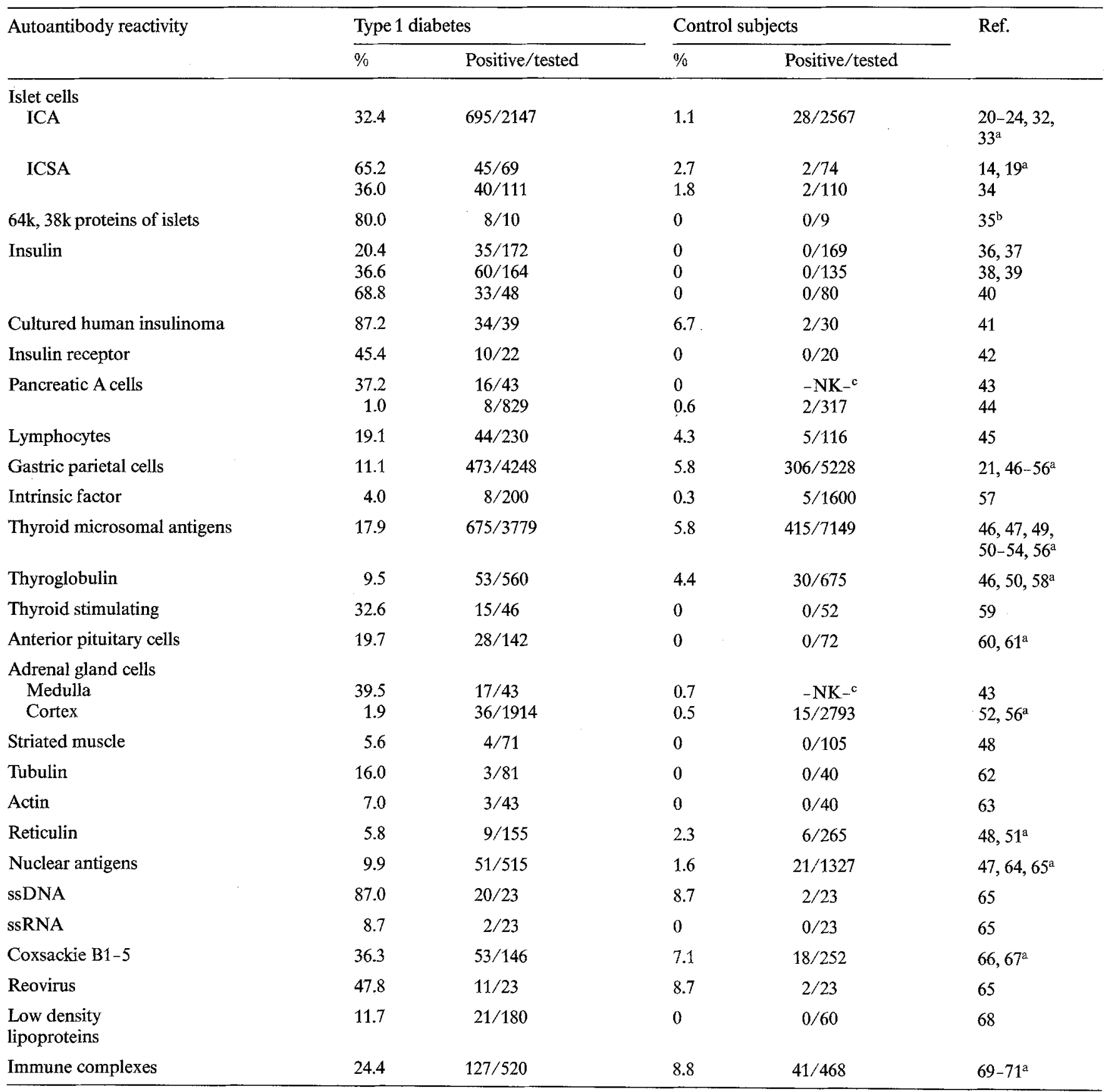

a Data pooled; ${ }^{b}$ data from [35] and personal communication; ${ }^{c}$ not known

44]. Despite the great variability and small sample size in certain studies, it is clear from the data summarized in Table 1 that patients with Type 1 diabetes mellitus have autoantibodies that are directed against a wide variety of non-pancreatic antigens in addition to those directed against islet cells.

\section{Duration of autoantibodies}

The frequency of ICA in the serum of Type 1 diabetic patients declines following diagnosis $[18,20,24,72-76]$.
From an initial frequency as high as $65 \%$ at diagnosis, the percentage of patients that have ICA declines to less than $20 \%$ after 2 years. This raises the question of whether other autoantibodies also decline with time. Unfortunately, only a limited amount of data are available to address this question $[18,20,21,24,32,45,47$, $60,62,63,70,72]$. Those autoantibodies for which data exist show a decline following diagnosis of diabetes similar to the decline in ICA (Table 2). Besides the decline in both ICA and ICSA, autoantibodies to lymphocytes present in $54.5 \%$ of a small number of Type 1 diabetic patients at diagnosis decrease to $25 \%$ within 
Table 2. Duration of autoantibodies after diagnosis of Type 1 diabetes mellitus

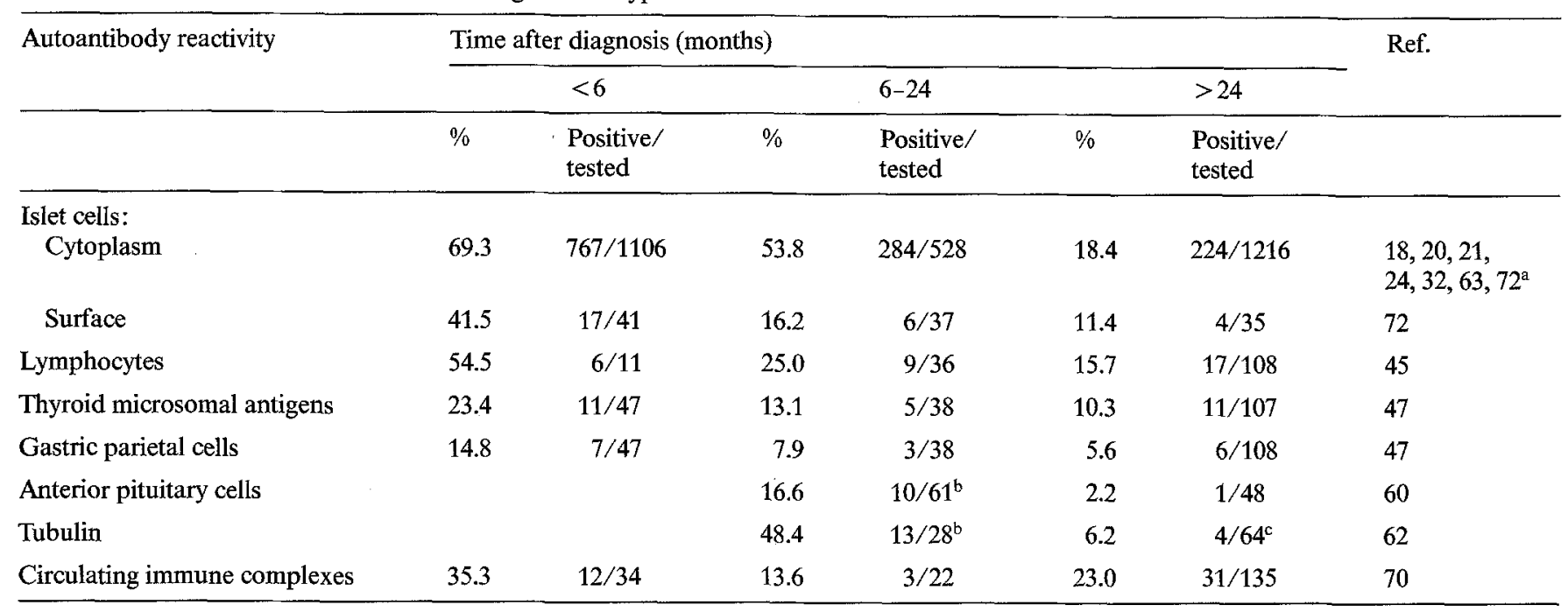

${ }^{\mathrm{a}}$ Data pooled; ${ }^{\mathrm{b}}$ data include patients from 0 to 24 months post-diagnosis; ${ }^{\mathrm{c}}$ duration greater than 6 years

6 months to 2 years and then to $15.7 \%$ after 2 years [45]. Similarly, autoantibodies to thyroid microsomes, reported in $23.4 \%$ of Type 1 diabetic patients within 6 months of diagnosis, decline to $13.1 \%$ after 6 months and $10.3 \%$ after 2 years [47]. It should be noted, however, that the frequency of autoantibodies to thyroid antigens appears to increase with age in the general population [53]. Further examination of the literature shows that autoantibodies to anterior pituitary cells, present in $16.6 \%$ of patients within 2 years of diagnosis of Type 1 diabetes, decline to $2.2 \%$ after 2 years [60]. Similar declines are reported for autoantibodies in Type 1 diabetic patients to gastric parietal cells [47] and tubulin [62], as well as for circulating immune complexes [70-72].

\section{Multiple abnormalities of cell-mediated immunity}

Table 3 summarizes some of the increasing number of reports [77-112] describing abnormalities of cell-mediated immunity (CMI) in Type 1 diabetes mellitus. It is clear from the table that the scope of activities described as cell-mediated is quite broad, and the reports are not always consistent. Several groups have reported decreases (ranging from $2 \%$ to $18 \%$ ) in total number of $T$ cells in the circulation of Type 1 diabetic patients [79-82], and a reduction in circulating helper T cells is thought to be responsible [80-82]. The ratio of circulating helper $\mathrm{T}$ cells to circulating cytotoxic/suppressor T cells is described as altered by a number of groups, but it remains controversial whether in Type 1 diabetic patients this ratio is decreased $[80,81,87]$ or increased $[82,84,86]$. Consistently, however, the percentage of activated T cells in the circulation, measured either as Interleukin-2 receptor-positive T cells [85] or as HLA DRantigen-positive $T$ cells $[81,86,87,89]$, is elevated in Type 1 diabetic patients. One report describes a decrease in Interleukin-2 production by $\mathrm{T}$ cells from Type 1 diabetic patients [90].
Other activities that have been reported to be abnormal in Type 1 diabetes mellitus include lymphocyte recognition of pancreatic antigens [91-94], phagocytic activity $[100,101]$, blastogenesis in response to insulin [97-99], as well as suppressor cell activities [93, 108, 110-113]. Additional reports describe increased K-cell reactivity [102], increased anti-islet-cell cytotoxicity $[103,104]$ and islet-specific suppressor cell activity [110]. Variable changes have been found in the mixed lymphocyte reaction (MLR) $[95,98]$ and mitogen responsiveness [96, 99, 105-109]. It is unclear, however, how much overlap there is in the immunological functions measured by the different assay systems. Moreover, different patient populations with varying degrees of metabolic control were used in these studies; this, in part, may account for the variation in results $[100,105,109]$. Selam et al. [105], for example, found that the percentage of total T cells in the circulation in 39 diabetic patients correlated with the degree of metabolic control. In 14 well-controlled diabetic patients, the percentage of total T cells in the circulation was $70.8 \%$, not different from the $71 \%$ in 50 non-diabetic control subjects. In contrast, in 25 poorly-controlled diabetic patients the percentage of $\mathrm{T}$ cells in the circulation was $64.1 \%$, significantly lower than the control subjects.

Perhaps the greatest source of uncertainty in interpreting these reports of abnormalities in cell-mediated immunity is that so few of them are islet cell specific. As more islet cell specific assays are developed, the extent of these abnormalities should become clearer.

\section{Duration of cell-mediated immunological abnormalities}

The data summarized in Table 4 show that some of the abnormalities in CMI return toward normal within 6 months to 2 years after diagnosis of Type 1 diabetes mellitus $[82,84,85,89,93,102,110,113]$. Topliss et al. 
Table 3. Cell-mediated immunity in Type 1 diabetes mellitus

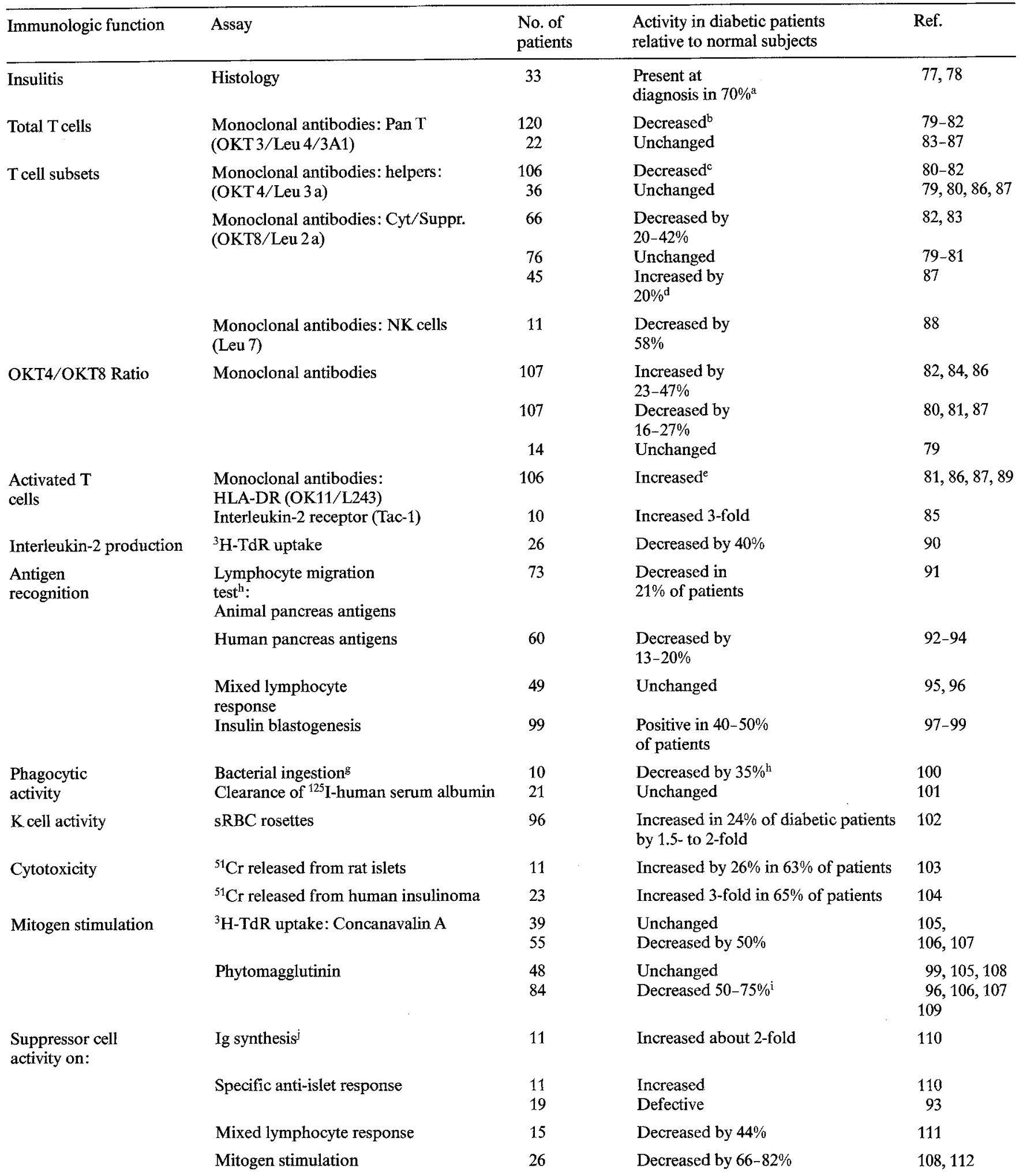

${ }^{a}$ Pooled data; ${ }^{\text {b }}$ decreases in overall circulating $\mathrm{T}$ cells vary from $2 \%$ to $18 \%$ in different studies; in general, the greatest decreases are seen in patients within 1 year of diagnosis; ${ }^{c}$ decreases in circulating helper $\mathrm{T}$ cells vary from $10 \%$ to $28 \%$ in different studies; in general, the greatest decreases are seen in patients within 1 year of diagnosis; ${ }^{\mathrm{d}}$ at diagnosis; ${ }^{\circ}$ circulating T cells expressing HLA-Dr antigens increased by $31.4 \%$ (34 patients) in [81]; increased 11.2-fold in 11 patients in [86]; increased 4.4-fold in 15 patients with recent-onset Type 1 diabetes ( $<6$ months), increased 2.2-fold in 28 patients with established Type 1 diabetes ( $>3$ years) in [89], and increased 2.5 -fold in 18 patients in [87]; ${ }^{\mathrm{f}}$ lymphokine production; ${ }^{\mathrm{g}}$ pneumococcus Type $2 ;^{\mathrm{h}}$ transient deficit; ameliorated by insulin treatment; ${ }^{\mathrm{i}}$ a much less pronounced decrease in mitogen responsiveness (approx. 10-15\%) was noted by Cacciari et al. [106]; ${ }^{j}$ immunoglobulins of all classes 
Table 4. Duration of cell-mediated immunologic abnormalities after diagnosis of Type 1 diabetes mellitus

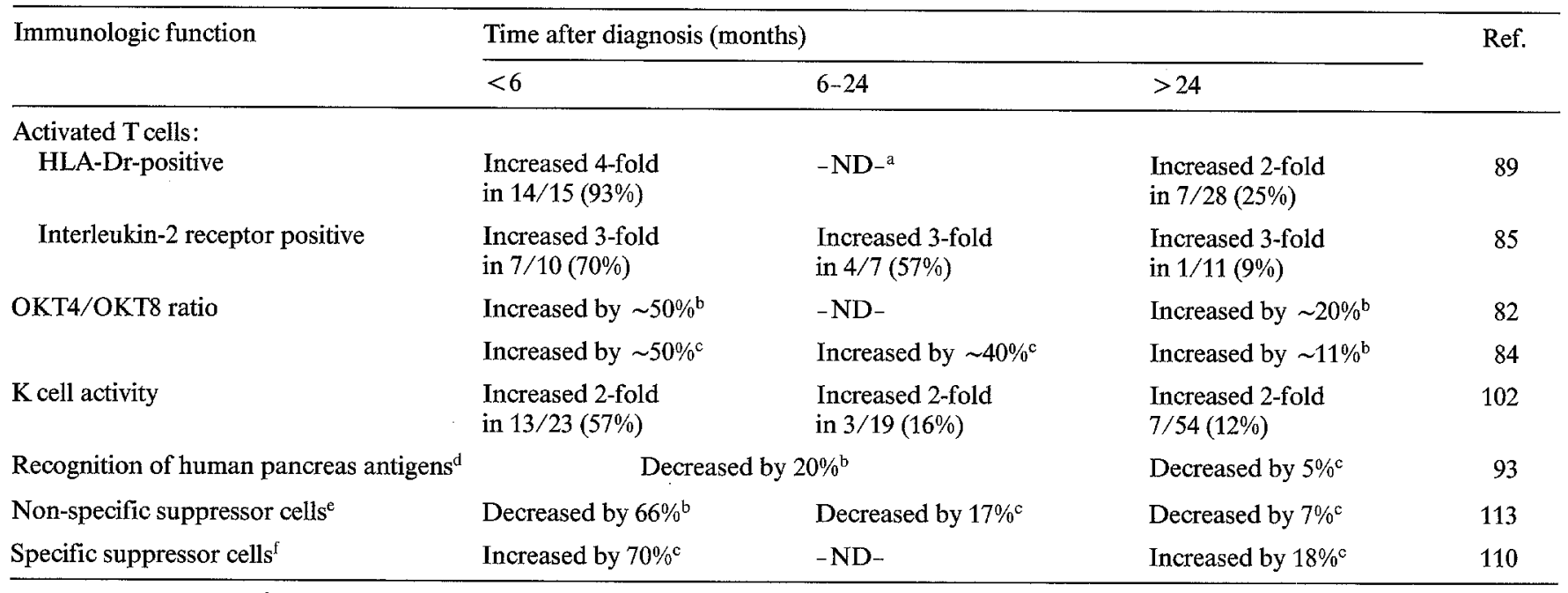

a ND, not determined; ${ }^{\mathrm{b}} n=12-33$ patients; ${ }^{\mathrm{c}} n=4-11$ patients; ${ }^{\mathrm{d}}$ migration of Tlymphocytes co-cultured with human pancreas antigen homogenate for $18 \mathrm{~h}$; ${ }^{\text {e }}$ suppression by Concanavalin-A activated T lymphocytes of Concanavalin-A stimulation of fresh heterologous Tlymphocytes (incorporation of ${ }^{3} \mathrm{H}-\mathrm{TdR}$ ); ${ }^{\mathrm{f}}$ guinea pig islet cell homogenate as test antigen

[93], using the leukocyte migration test (which measures antigen-stimulated lymphokine release), found that 19 diabetic patients with disease for less than 2 years gave an average response to human pancreas antigen of $0.81 \pm 0.05$, while 10 diabetic patients studied more than 2 years after diagnosis responded with an average migration index of $0.95 \pm 0.23$ (1.0 being normal). Buschard et al. [113] found that non-specific Concanavalin-A-induced suppressor activity returned toward normal values with a low of $0.34 \pm 0.16$ at or near diagnosis to $0.83 \pm 0.16$ in the 6-month to 2-year interval, and up to $0.93 \pm 0.15$ beyond 2 years ( 1.0 being normal). In other experiments, Pozzilli et al. [102] reported that $57 \%$ of newly diagnosed diabetic patients had elevated K-cell activity, and that this decreased to $16 \%$ between 6 months and 2 years after diagnosis. In studies of Interleukin-2 receptor expression on circulating T cells, Hayward and Herberger [85] reported that in 15 recently diagnosed diabetic patients, $6.2 \%$ of the lymphocytes had Interleukin-2 receptors, whereas in six diabetic patients with disease for longer than 2 years, only $2.3 \%$ of the lymphocytes had Interleukin- 2 receptors $(2 \%$ of control lymphocytes were Interleukin-2 receptor-positive). Two reports $[82,84]$ studying OKT4/OKT8 ratios in diabetic patients showed elevated values at or near diagnosis and decreased values after 1 or more years of disease.

\section{Immunological abnormalities associated with experimental induction of diabetes}

The possibility that some of the immunological abnormalities found in Type 1 diabetes mellitus might be secondary to pancreatic B-cell destruction and insulin deficiency was explored by reviewing the literature on chemicals (i.e. alloxan and streptozotocin) that induce diabetes in experimental animals by destroying B cells [114-116]. Other animal models of diabetes involving more complicated etiologies have been reviewed elsewhere $[1,116,117]$. The data summarized in Table 5 [118-127] show that in animals with alloxan-induced diabetes, a number of immunological functions are depressed, including cellularity of the lymphoid organs $[118,119]$, contact sensitivity to haptens $[120,121]$, granuloma formation [122], delayed-type hypersensitivity (DTH) reactions [122, 124], humoral antibody responses $[119,123,124]$ and the response to mitogens $[124,127]$. In addition, the rejection time of skin grafts was prolonged [119].

Similarly, single-dose streptozotocin-treated mice showed many immunological abnormalities $[122,124$, 128-135]. As in alloxan-treated mice, lymphoid organ cellularity [128-132], hapten sensitivity [130,133], delayed-type hypersensitivity $[122,124,131]$, humoral antibody responses $[124,131,133,134]$, mitogen responses $[124,132]$ and phagocytic activity $[133,135]$ were all reduced. Reductions in the mixed lymphocyte reaction [129], the generation of cytotoxic lymphocytes [129, 134], tumour rejection [129] and allograft rejections [122] were also observed. Thus, many of the immunological abnormalities in chemically-induced diabetes parallel the abnormalities seen in human Type 1 diabetes (Tables 1, 3).

\section{Restoration of immune function in vivo by insulin}

Although it is tempting to attribute these immunological abnormalities to pancreatic B-cell destruction and a deficiency of insulin, streptozotocin and alloxan might have a direct injurious effect on the cells of the immune 
Table 5. Immunological abnormalities following drug-induced Type 1 diabetes mellitus in experimental animals

\begin{tabular}{|c|c|c|c|c|c|}
\hline Induction of diabetes $^{\mathrm{a}}$ & Immune function & Assay & Effect & Restoration by insulin & Ref. \\
\hline \multirow{8}{*}{$\begin{array}{l}\text { Alloxan: } \\
75-200 \mathrm{mg} / \mathrm{kg} \\
\text { one injection }\end{array}$} & $\begin{array}{l}\text { Cellularity } \\
\text { of lymphoid organs }\end{array}$ & $\begin{array}{l}\text { Cell count } \\
\text { in spleen and thymus }\end{array}$ & Reduced by $80-90 \%$ & $\begin{array}{l}\text { Restored to } \\
80-90 \% \text { of normal }\end{array}$ & 118,119 \\
\hline & $\begin{array}{l}\text { Contact sensitivity } \\
\text { to oxazalone or DNFB }\end{array}$ & Ear swelling & Reduced by $70-77 \%$ & $\begin{array}{l}\text { Restored to } \\
58 \% \text { of normal }\end{array}$ & 120,121 \\
\hline & Granuloma formation & S. mansoni eggs & Reduced by $65-70 \%$ & $\begin{array}{l}\text { Restored to } \\
90 \% \text { of normal }\end{array}$ & 122 \\
\hline & $1^{\circ}, 2^{\circ} \mathrm{Ab}$ response & PFC assay & Reduced by $60-80 \%$ & $\begin{array}{l}\text { Restored to } \\
100 \% \text { of normal }\end{array}$ & $119,123,124$ \\
\hline & Phagocytic functions & Bacterial ingestion & $\begin{array}{l}\text { Normal } \\
\text { Reduced by } 20-60 \%\end{array}$ & $\begin{array}{l}-\mathrm{ND}-\mathrm{b} \\
-\mathrm{ND}-\end{array}$ & $\begin{array}{l}118 \\
125,126\end{array}$ \\
\hline & $\begin{array}{l}\text { Delayed type } \\
\text { hypersensitivity }\end{array}$ & Foot pad swelling & Reduced by $75-85 \%$ & $\begin{array}{l}\text { Restored to } \\
100 \% \text { of normal }\end{array}$ & 122,124 \\
\hline & $\begin{array}{l}\text { Mitogen responsiveness } \\
\text { (PHA, Concanavalin-A) }\end{array}$ & ${ }^{3} \mathrm{H}-\mathrm{TdR}$ uptake & Reduced by $25-60 \%$ & $\begin{array}{l}\text { Restored to } \\
100 \% \text { of normal }\end{array}$ & 124,127 \\
\hline & Allograft rejection & Skin grafting & Prolonged by $4-7$ days & Restored & 119 \\
\hline \multirow{12}{*}{$\begin{array}{l}\text { Streptozotocin } \\
100-200 \mathrm{mg} / \mathrm{kg} \\
\text { one injection }\end{array}$} & Cellularity & $\begin{array}{l}\text { Cell counts } \\
\text { in spleen and thymus }\end{array}$ & Reduced by $50-95 \%$ c & $\begin{array}{l}\text { Restored to } \\
\sim 60 \% \text { of normal }\end{array}$ & $128-132$ \\
\hline & $\begin{array}{l}\text { Contact sensitivity to } \\
\text { oxazalone or DNFB }\end{array}$ & Ear swelling & Reduced by $50-80 \%$ & None & 130,133 \\
\hline & Granuloma formation & S. mansoni eggs & Reduced by $20-68 \%$ & Restored to normal & 122 \\
\hline & $1^{\circ}, 2^{\circ} \mathrm{Ab}$ responses & PFC assay & Reduced by $70-99 \%$ & $\begin{array}{l}\text { Restored to } \\
\sim 75 \% \text { of normal } \\
\end{array}$ & $\begin{array}{l}124,131,133, \\
134\end{array}$ \\
\hline & Phagocytic activity & Bacterial ingestion & Reduced by $90 \%$ & $\begin{array}{l}-\mathrm{ND}- \\
\text { Restored to } \\
\sim 67 \% \text { of normal }\end{array}$ & $\begin{array}{l}133 \\
135\end{array}$ \\
\hline & $\begin{array}{l}\text { Mitogen responsiveness } \\
\text { (Con-A, LPS, PWMe) }\end{array}$ & ${ }^{3} \mathrm{H}-\mathrm{TdR}$ uptake & Reduced by $50-75 \%{ }^{c}$ & $\begin{array}{l}\text { Restored to } \\
\sim 75 \% \text { of normal }\end{array}$ & 124,132 \\
\hline & $\begin{array}{l}\text { Delayed type } \\
\text { hypersensitivity }\end{array}$ & Foot pad swelling & Reduced by $40-90 \%$ & $\begin{array}{l}\text { Restored to } \\
\sim 75 \% \text { of normal }\end{array}$ & $122,124,131$ \\
\hline & $\begin{array}{l}\text { Resistance to } \\
\text { M.tuberculosis }\end{array}$ & Survival & Reduced by $80 \%$ & $-\mathrm{ND}-$ & 133 \\
\hline & $\begin{array}{l}\text { Mixed lympho- } \\
\text { cyte response }\end{array}$ & ${ }^{3} \mathrm{H}-\mathrm{TdR}$ uptake & $\begin{array}{l}\text { Reduced by } 50 \% \text { f } \\
\text { No change }\end{array}$ & $\begin{array}{l}-\mathrm{ND}- \\
-\mathrm{ND}\end{array}$ & $\begin{array}{l}129 \\
132\end{array}$ \\
\hline & $\begin{array}{l}\text { Generation of } \\
\text { cell mediated } \\
\text { lympholysis }\end{array}$ & ${ }^{51} \mathrm{Cr}$ release & Reduced by $50-90 \%$ & $\begin{array}{l}\text { Restored to } 100 \% \text { of } \\
\text { normal }^{\mathrm{d}}\end{array}$ & 129,134 \\
\hline & Allograft rejection & Skin grafting & Prolonged by 4 days & $-\mathrm{ND}-$ & 122 \\
\hline & Tumour rejection & $\begin{array}{l}\text { Growth of syngeneic, } \\
\text { UV-induced tumour }\end{array}$ & Reduced by $\sim 75 \% \mathrm{~g}$ & None & 129 \\
\hline
\end{tabular}

${ }^{a}$ Mice, unless otherwise noted; ${ }^{b} \mathrm{ND}$, not done; ${ }^{\mathrm{c}}$ data include Sprague-Dawley rats [132]; ${ }^{\mathrm{d}}$ complete restoration reported via islet cell transplantation [134]; ${ }^{\mathrm{e}}$ pokeweed mitogen; ${ }^{\mathrm{f}}$ at 9 days only; thereafter MLR was normal; ${ }^{\mathrm{g}}$ tested in mice 31 days after streptozotocin administration; subcutaneous tumour growth was evaluated 35 days post-implantation with tumour fragments

system. In vitro experiments [124] have shown that streptozotocin decreased the viability of spleen and thymus cells, anti-SRBC plaque formation, PHA-, Concanavalin-A and LPS-responses, and Interleukin-1 and Interleukin-2 production. In contrast, up to 10 times the in vivo diabetogenic dose $(1.1 \mathrm{mmol} / \mathrm{l})$ of alloxan had little or no effect on in vitro immune function [124]. Nonetheless, the evidence that pancreatic B-cell destruction and the decrease in circulating insulin in alloxan-treated animals is responsible for the alterations in immune function must be interpreted with caution. Probably the best evidence that insulin deficiency can alter immune function comes from restoration experiments. As seen in Table 5, insulin therapy can partially or completely restore a number of the immunological abnormalities $[119,120,122,124,127,129,130,134$, 135]. More consistent reversals of immune deficits were achieved in alloxan-induced diabetes than in streptozotocin-induced diabetes. In alloxan-induced diabetic mice, complete or near complete restoration of lym- 
Table 6. Effect of insulin on in vitro immune functions

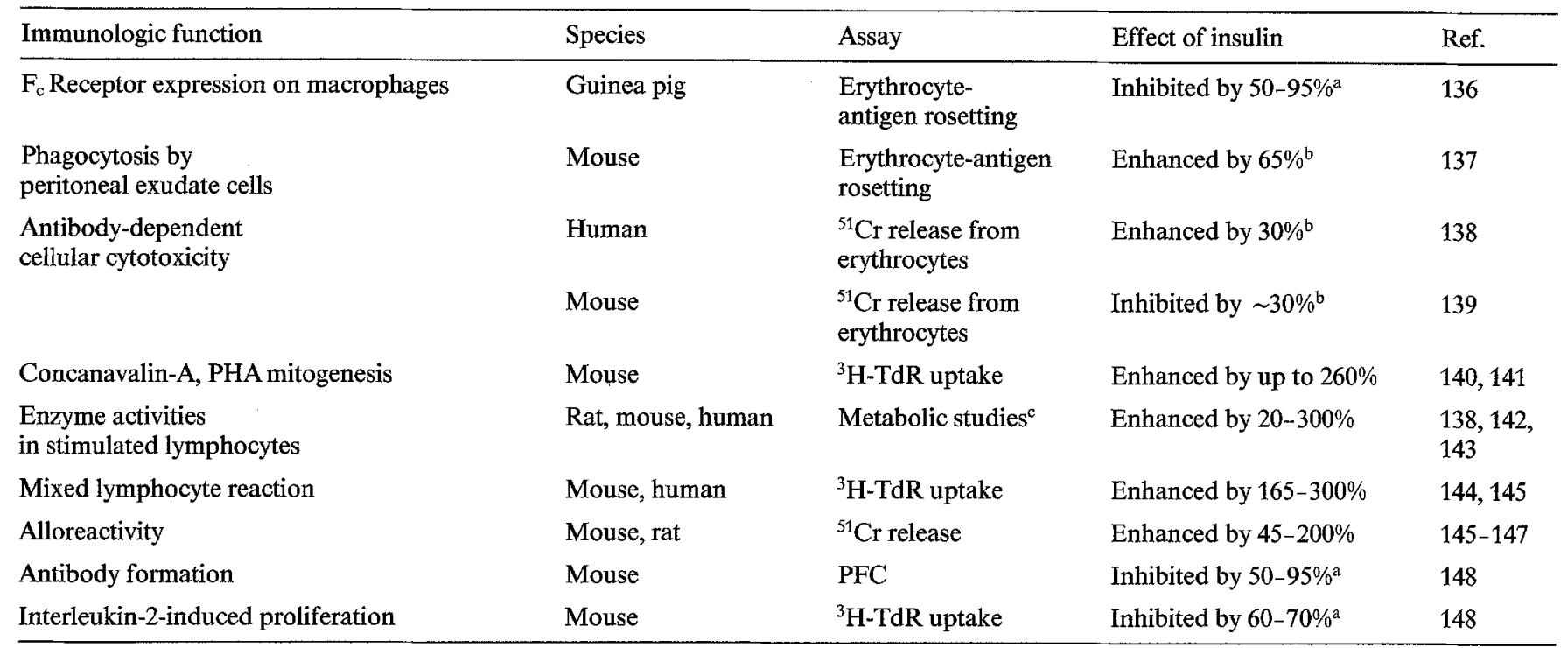

a Nonphysiologic doses of insulin $\left(5 \times 10^{-5} \mathrm{~mol} / 1\right){ }^{b}$ physiologic levels of insulin $\left(10^{-9}-10^{-13} \mathrm{~mol} / 1\right)$; $^{\mathrm{c}}$ glucose oxidation. lactate oxidation, pyruvate kinase, lactic dehydrogenase, lactate release, glucose uptake

phoid organ cellularity, granuloma formation [122], antibody responses [119, 123, 124], graft rejection [119], Concanavalin-A responsiveness [124] and DTH reactions [124] have been reported. In streptozotocin-induced diabetic animals, partial restorations of lymphoid organ cellularity $[129,130]$, antibody responses $[124,134]$, Concanavalin-A responsiveness and DTH responses [124] were achieved.

\section{Effects of insulin on in vitro immune function}

Further evidence that insulin can affect the function of the immune system comes from a variety of in vitro experiments (Table 6) [136-148]. Rhodes [136] reported that insulin inhibited the expression of Fc receptors on guinea pig macrophages as measured by an erythrocyteantibody rosetting assay, but the concentration of insulin employed was in the $5 \times 10^{-5} \mathrm{~mol} / 1 \mathrm{range}$; this is three to seven orders of magnitude larger than the concentration commonly regarded as physiological [137-139]. Similarly, Hunt and Eardley [148] reported inhibition of antibody formation and Interleukin-2-induced proliferation by these concentrations of insulin. When Lima et al. [137] used insulin in physiological doses $\left(10^{-9}\right.$ to $\left.10^{-13} \mathrm{~mol} / \mathrm{l}\right)$, they found enhancement of phagocytic responses by murine peritoneal macrophages, a result confirmed by Kragballe et al. [138] using human monocytes. Using a different assay Bar et al. [139] reported inhibition of antibody-dependent cellular cytotoxicity by insulin $\left(10^{-10} \mathrm{~mol} / \mathrm{l}\right)$, but the inhibition was not dramatic (about 30\%).

Most investigators believe that resting lymphocytes are unresponsive to insulin because they do not express insulin receptors $[140,142,144,149]$. Thus, for insulin to affect lymphocyte function, the lymphocytes must first become activated. Activation can occur following antigenic challenge, mitogen stimulation or co-culture with allogeneic cells $[143,149,150]$. In general, insulin enhances the responsiveness of already activated lymphocytes. Several investigators $[140,142,143]$ have reported that insulin can increase the stimulation of murine lymphocytes by the mitogens PHA, Concanavalin-A and LPS. Others $[138,151]$ have noted similar in vitro effects of insulin on the metabolic activity of human leukocytes. Numerous reports on insulin-enhanced functions on activated cells have appeared as well. In vitro and in vivo, insulin increases murine plaque formation to sheep erythrocytes $[143,152]$, the mixed leukocyte reaction in both murine and human cultures $[144,145]$, and the development of cytotoxic effector cells lytic for ${ }^{51} \mathrm{Cr}-$ labeled alloantigenic target cells [146, 147]. In vivo, it has been reported that the administration of insulin causes transient changes in human peripheral T-cell subsets [153]. Taken together, these studies show that, directly or indirectly, insulin can alter immune function.

\section{Comment}

A review of the literature makes several points clear. First, although much attention has been given to ICA, autoantibodies to a variety of other tissues are present in patients with Type 1 diabetes mellitus. Moreover, patients with Type 1 diabetes show a number of cell-mediated immunological abnormalities. If Type 1 diabetes is triggered by a specific attack on pancreatic B cells, why are autoantibodies present that react with other tissues of the body? Although some antibodies to pancreatic B cells may cross-react with the other tissues, it seems unlikely that this is the sole explanation for the multiple organ-reactivity serum from patients with Type 1 diabe- 
tes [154]. A number of different antigen-specific antibody molecules are almost certainly present. If this is the case, one must then ask whether the antibodies to pancreatic B cells appear as part of a broader immunological dysfunction associated with Type 1 diabetes or whether these antibodies develop as a consequence of the disease process. The answer to this question is of central importance to understanding the etiology of Type 1 diabetes, and may help determine whether the primary defect resides in pancreatic B cells or in cells of the immune system.

The second point that a review of the literature makes clear is that certain of the immunological abnormalities are transient. For example, the frequency of ICA in Type 1 diabetes decreases from over $60 \%$ at the time of the initial diagnosis to less than $20 \%$ at 2 years after diagnosis. It is generally thought that this decrease in ICA reflects a loss of antigenic stimulation due to the depletion of the remaining pancreatic $B$ cells. However, the data in Tables 2 and 4 make it clear that antibodies to tissues other than pancreatic B cells also decrease after diagnosis, and that a number of the cell-mediated immunological abnormalities return towards normal. In contrast to Type 1 diabetes, in other autoimmune diseases the autoantibodies may persist for years $[155,156]$.

One fundamental difference between the pre- and post-diagnosis phase of Type 1 diabetes mellitus is that after diagnosis the patients are treated with maintenance doses of insulin. This raises the question as to whether insulin can influence immunlogical function. A review of the literature (Tables 5, 6) shows that insulin can have a profound effect on at least some immunological functions. Less clear is whether insulin deficiency induces the type of immunological abnormalities seen in Type 1 diabetes. If insulin deficiency does play a rôle, there are several possible modes of action. The first is that the destruction of pancreatic B cells is the result of an immunologically specific attack on B cells, triggered by still unknown factors, and that the generation of autoantibodies against non-pancreatic tissues is a consequence of the resulting insulin deficiency on the normal function of the immune system. The second is that an environmental insult (e.g. viruses or toxins) damages pancreatic $B$ cells $[4,157]$, and that the rise of autoantibodies to both pancreatic islets and non-pancreatic tissues is in part due to the resulting insulin deficiency and the effect it has on the normal function of the immune system. In either case, the administration of insulin after diagnosis, and the at least partial correction of host metabolism, might be responsible for the observed restoration of immunological function (Table 2). Some support for this argument also comes from experiments in diabetic animals which have shown that administration of insulin can correct some of the immunological abnormalities (Table 5). A third possibility is that glycosylation of proteins $[158,159]$, which is known to be increased in Type 1 diabetes, makes self antigens foreign and induces autoantibodies. The administration of insulin would result in a decline of glycosylated proteins and a corresponding decrease in autoantibodies. A number of questions, however, remain to be answered and additional and more rigorous information is needed to determine if a deficiency or abnormality in insulin secretion truly plays a rôle. For example, does diabetes caused by partial pancreatectomy (to avoid the use of drugs that might affect lymphocyte function) in experimental animals induce immunological abnormalities? In humans, do subsets of lymphocytes from DR3 and DR4 individuals (who are known to be at higher risk of developing Type 1 diabetes) $[160,161]$ show more immunological abnormalities than lymphocytes from individuals with other HLA types if subjected to hypoinsulinaemia and hyperglycaemia? In high-risk first degree relatives of Type 1 diabetic patients, does the time of appearance of autoantibodies to non-pancreatic tissues correlate with the time of appearance of autoantibodies to pancreatic islets?

The work summarized here raises the possibility that immunological abnormalities may not only be a cause, but one of the complications of Type 1 diabetes mellitus. More information on this and related issues may provide useful clues to therapy. Aggressive insulin therapy has been used by some investigators to prolong the remission ("honeymoon") period [162-164]. It has been suggested that insulin acts by preventing exhaustion of the remaining pancreatic $B$ cells. Another possibility is that insulin may partially restore the altered function of the immune system, thereby slowing the autoimmune process. It is of interest that in patients with Type 2 (non-insulin-dependent) diabetes mellitus, immunological abnormalities are not common.

In conclusion, Type 1 diabetes mellitus is characterized by multiple and in some cases transient immunological abnormalities. The idea that a deficiency in insulin or its aberrant regulation may be responsible for certain of the immunological abnormalities associated with Type 1 diabetes has appeal, but has not been fully proven. What actually triggers the cascade of events leading to pancreatic B-cell destruction, and whether the primary defect resides at the level of the target cells or effector cells, also remains elusive.

\section{References}

1. Rossini AA, Mordes JP, Like AA (1984) Animal models of insulin-dependent diabetes mellitus. In: Immunology in diabetes. Andreani D, DiMario U, Federlin KF, Heding LG (eds) Kimpton, London, pp 35-44

2. Bottazzo GF (1984) $\beta$-cell damage in diabetic insulitis: are we approaching a solution? Diabetologia 26: 241-249

3. Eisenbarth GS (1986) Type 1 diabetes mellitus. A chronic autoimmune disease. N Engl J Med 314: 1360-1368

4. Notkins AL, Yoon JW (1984) Virus-induced diabetes mellitus. In: Concepts in viral pathogenesis. Notkins AL, Oldstone MBA (eds) Springer, New York, pp 241-247 
5. Toniolo A, Onodera T (1984) Viruses and diabetes. In: Immunology in diabetes. Andreani D, DiMario U, Federlin KF, Heding LG (eds) Kimpton, London, pp 71-93

6. Bottazzo GF, Pozzilli P, Mirakian R, Dean BM, Doniach D (1984) Early immunological events in diabetes. In: Immunology in diabetes. Andreani D, DiMario U, Federlin KF, Heding LG (eds) Kimpton, London, pp 95-104

7. Rossini AA, Mordes JP, Like AA (1985) Immunology of insulindependent diabetes mellitus. Ann Rev Immunol 3: 289-320

8. Nerup J, Lernmark A, Scott J (1984) Autoimmunity. In: Immunology of clinical and experimental diabetes. Gupta $S$ (ed) Plenum, New York, pp 351-367

9. Irvine WJ (1980) Autoimmunity and diabetes. In: Autoimmune aspects of endocrine disorders. Pinchera A, Doniach D, Fenzi GF, Baschieri L (eds) Academic Press, London, pp 249-274

10. Handwerger BS (1985) The immunology of diabetes mellitus. In: Autoimmunity and endocrine disease. Volpe R (ed) Marcel Dekker, New York, pp 287-344

11. Dobersen MJ (1985) Humoral autoimmune aspects of insulin-dependent (Type 1) diabetes mellitus. Concepts Immunopathol 2: $47-64$

12. Papadopoulos GK, Lernmark A (1983) The spectrum of islet cell antibodies. In: Autoimmune endocrine disease. Davies TF (ed) Wiley, New York, pp 167-180

13. Herold KC, Huen AH-J, Rubenstein AH, Lernmark A (1984) Humoral abnormalities in type 1 (insulin-dependent) diabetes mellitus. In: Immunology in diabetes. Andreani D, DiMario U, Federlin KF, Heding LG (eds) Kimpton, London, pp 105-120

14. Dobersen MJ, Scharff JE, Ginsberg-Fellner F, Notkins AL (1980) Cytotoxic autoantibodies to beta cells in the serum of patients with insulin-dependent diabetes mellitus. N Engl J Med 303: 1493-1498

15. Eisenbarth GS, Morris MA, Scearce RM (1981) Cytotoxic antibodies to cloned rat islet cells in serum of patients with diabetes mellitus. J Clin Invest 67: 403-408

16. Brogren CH, Lernmark A (1982) Islet cell antibodies in diabetes. Clin Endocrinol Metab 11: 409-430

17. Huen AH-J, Haneda M, Freedman Z, Lernmark A, Rubenstein AH (1983) Quantitative determination of islet cell surface antibodies using ${ }^{125} \mathrm{I}$-protein $\mathrm{A}$. Diabetes $32: 460-465$

18. Kolb H, Stroheker M, Biener J, Gruneklee D, Muntefering $H$, Gries FA (1980) Analysis of the persistence of islet cell antibodies and islet cell type-specific antibodies in type 1 diabetic children. In: Autoimmune aspects of endocrine disease. Pinchera A, Doniach D, Fenzi GF, Baschieri L (eds) Academic Press, London, pp 291-294

19. Riley W, Maclaren N (1984) Islet cell antibodies are seldom transient. Lancet 1: 1351-1352

20. Irvine WJ, McCallum CJ, Gray RS, Campbell CJ, Duncan LJP, Farquhar JW, Vaughan H, Morris PJ (1977) Pancreatic islet-cell antibodies in diabetes mellitus correlated with the duration and type of diabetes, coexistent autoimmune disease, and HLA type. Diabetes 26: 138-147

21. Bright GM, Blizzard RM, Kaiser DL, Clarke WL (1982) Organspecific autoantibodies in children with common endocrine diseases. J Pediatr 100: 8-14

22. Del Prete GF, Betterle C, Padovan D, Erle G, Toffolo A, Bersahi G (1977) Incidence and significance of islet-cell autoantibodies in different types of diabetes mellitus. Diabetes 26: 909-915

23. Rodger B, Whittingham S, Martin FIR, Hawkins BR, Dawkins RL, Welborn TA (1980) A population survey of pancreatic islet cell antibodies. Clin Exp Immunol 39: 125-129

24. Lendrum R, Walker G, Cudworth AG, Theophanides C, Pyke DA, Bloom A, Gamble DR (1976) Islet-cell antibodies in diabetes mellitus. Lancet 2: 1273-1276

25. Gorsuch AN, Lister J, Dean BM, Spencer KN, McNally JM, Bottazzo GF, Cudworth AG (1981) Evidence for a long prediabetic period in type 1 (insulin-dependent) diabetes mellitus. Lancet 2 : 1363-1365
26. Srikanta S, Ganda OP, Eisenbarth GS, Soeldner JS (1983) Isletcell antibodies and beta-cell function in monozygotic triplets and twins initially discordant for type 1 diabetes mellitus. N Engl J Med 308: 322-325

27. Mustonen A, Knip M, Huttunen N-P, Puukka R, Kaar M-L, Akerblom HK (1984) Evidence of delayed $\beta$-cell destruction in type 1 (insulin-dependent) diabetic patients with persisting complement-fixing cytoplasmic islet cell antibodies. Diabetologia 27 : 421-426

28. Ginsberg-Fellner F, Witt ME, Franklin BH, Yagihashi S, Toguchi Y, Dobersen MJ, Rubenstein P, Notkins AL (1985) Triad of markers for identifying children at high risk of developing insulin-dependent diabetes mellitus. J Am Med Assoc 254: 1469-1472

29. Irvine WJ (1980) Immunological aspects of diabetes mellitus: a review. (1980) In: Immunology of diabetes. Irvine WJ (ed) Teviot, Edinburgh, pp 1-53

30. Nerup J, Lernmark A (1981) Autoimmunity in insulin-dependent diabetes mellitus. Am J Med 70: 135-141

31. Maclaren NK, Riley WJ (1985) Thyroid, gastric, and adrenal autoimmunities associated with insulin-dependent diabetes mellitus. Diabetes Care 8 [Suppl 1]: 34-38

32. Bottazzo GF, Mann JI, Thorogood M, Baum JD, Doniach D (1978) Autoimmunity in juvenile diabetics and their families. $\mathrm{Br}$ Med J 2: 165-168

33. Notsu K, Oka N, Note S, Nabeya N, Kuno S, Sakurami T (1985) Islet cell antibodies in the Japanese population and subjects with Type-1 (insulin-dependent) diabetes. Diabetologia 28: 660-662

34. Toguchi Y, Ginsberg-Fellner F, Rubenstein P (1985) Cytotoxic islet cell surface antibodies (ICSA) in patients with Type 1 diabetes and their first-degree relatives. Diabetes 34: 855-860

35. Baekkeskov S, Nielsen JH, Marner B, Bilde T, Ludvigsson J, Lernmark A (1982) Autoantibodies in newly diagnosed diabetic children immunoprecipitate human pancreatic islet-cell proteins. Nature 298: 167-169

36. Palmer JP, Asplin CM, Clemons P, Lyen K, Tatpati O, Raghu PK, Paquette TL (1983) Insulin antibodies in insulindependent diabetics before insulin treatment. Science 222: 1337-1339

37. Karjalainen J, Knip M, Mustonen A, Ilonen J, Akerblom HK (1986) Relation between insulin antibody and complement-fixing islet cell antibody at clinical diagnosis of IDDM. Diabetes 35: 620-622

38. Wilkin T, Armitage M, Casey C, Pyke DA, Hoskins PJ, Rodier M, Diaz JL, Leslie RDG (1985) Value of insulin autoantibodies as serum markers for insulin-dependent diabetes mellitus. Lancet 1: $480-482$

39. Arslanian SA, Becker DJ, Rabin B, Atchison R, Eberhardt M, Cavender D, Dorman J, Drash AL (1985) Correlates of insulin antibodies in newly diagnosed children with insulin-dependent diabetes before insulin therapy. Diabetes 34: 926-930

40. McEvoy RC, Witt ME, Ginsberg-Fellner F, Rubinstein P (1986) Anti-insulin antibodies in children with type 1 diabetes mellitus. Genetic regulation of production and presence at diagnosis before insulin replacement. Diabetes 35: 634-641

41. Maclaren NK, Huang S-W, Fogh J (1975) Antibody to cultured human insulinoma cells in insulin-dependent diabetes. Lancet 1: 997-1000

42. Maron R, Elias D, de Jongh BM, Bruining GJ, van Rood JJ, Schechter Y, Cohen IR (1983) Autoantibodies to the insulin receptor in juvenile onset insulin-dependent diabetes. Nature 303: 817-818

43. Schopfer K, Matter L, Tenschert R, Bauer S, Zuppinger K (1984) Anti-glucagon-cell and anti-adrenal-medullary-cell antibodies in islet-cell-autoantibody-positive diabetic children. N Engl J Med 310: 1536-1537

44. Bottazzo GF, Lendrum R (1976) Separate autoantibodies to human pancreatic glucagon and somatostatin cells. Lancet 2: 873-876

45. Serjeantson S, Theophilus J, Zimmet P, Court J, Crossley JR, El- 
liott RB (1981) Lymphocytotoxic antibodies and histocompatibility antigens in juvenile-onset diabetes mellitus. Diabetes 30: 26-29

46. Srikanta S, Malaviya AN; Mehra NK, Vaidya MC, Geevarghese PJ, Ahuja MMS (1981) Autoimmunity in type 1 (insulindependent) diabetes mellitus in North India. J Clin Immunol 1: 169-173

47. Nagaoka K, Sakurami T, Nabeya N, Imura H, Kuno S (1979) Antimicrosomal antibodies, gastric parietal cell antibodies and antinuclear factors in insulin-dependent diabetes mellitus. Endocrinol Jpn 26:599-603

48. Dorchy H, Lemiere B, Toussaint D, Gausset P (1981) Anticorps anticellules des ilots de Langerhans et specifiques d'organes chez les jeunes diabetiques. Nouv Presse Med 10: 2795-2798

49. Goldstein E, Drash A, Gibbs J, Blizzard RM (1970) Diabetes mellitus: the incidence of circulating antibodies against thyroid, gastric, and adrenal tissue. J Pediatr 77:304-306

50. Nerup J, Binder C (1973) Thyroid, gastric and adrenal auto-immunity in diabetes mellitus. Acta Endocrinol 72: 279-286

51. Kokkonen J, Kiuttu J, Mustonen A, Rasanen O (1982) Organspecific antibodies in healthy and diabetic children and young adults. Acta Paediatr Scand 71: 223-226

52. Betterle C, Zanette F, Pedini B, Presotto F, Rapp LB, Monciotti CM, Rigon F (1984) Clinical and subclinical organ-specific autoimmune manifestations in Type 1 (insulin-dependent) diabetic patients and their first-degree relatives. Diabetologia 26: 431-436

53. Irvine WJ, Scarth L, Clarke BF, Cullen R, Duncan LJP (1970) Thyroid and gastric autoimmunity in patients with diabetes mellitus. Lancet 2: 163-168

54. Neufeld M, Maclaren NK, Riley WJ, Lezotte D, McLaughlin JV, Silverstein J, Rosenbloom AL (1980) Islet cell and other organspecific antibodies in US Caucasians and Blacks with insulindependent diabetes mellitus. Diabetes 29: 589-592

55. Whittingham S, Mathews JD, Mackay IR, Stocks AE, Ungar B, Martin FIR (1971) Diabetes mellitus, autoimmunity and ageing. Lancet 1: 763-767

56. Ketchum CH, Riley WJ, Maclaren NK (1984) Adrenal dysfunction in asymptomatic patients with adrenocortical autoantibodies. J Clin Endocrinol Metab 58: 1166-1170

57. Ungar B, Stocks AE, Martin FIR, Whittingham S, Mackay IR (1968) Intrinsic-factor antibody, parietal-cell antibody, and latent pernicious anaemia in diabetes mellitus. Lancet 2: 415 -418

58. Simkins S (1968) Antithyroglobulin antibodies in diabetes mellitus. Diabetes 17: 136-140

59. Bliddal H, Bech K, Johansen K, Nerup J (1984) Thyroid-stimulating immunoglobulins in insulin-dependent diabetes mellitus. Eur J Clin Invest 14: 474-478

60. Mirakian R, Bottazzo GF, Cudworth AG, Richardson CA, Doniach D (1982) Autoimmunity to anterior pituitary cells and the pathogenesis of insulin-dependent diabetes mellitus. Lancet 1 : 755-759

61. Sugiura M, Hashimoto A, Shizawa M, Tsukada M, Maruyama S, Ishido T, Kasahara T, Hirata Y (1986) Heterogeneity of anterior pituitary cell antibodies detected in insulin-dependent diabetes mellitus and adrenocorticotropic hormone deficiency. Diabetes Res 3: 111-114

62. Rousset B, Vialettes B, Bernier-Valentin F, Vaque $P$, Mornex R (1984) Anti-tubulin antibodies in recent onset type 1 (insulin-dependent) diabetes mellitus: comparison with islet cell antibodies. Diabetologia 27: 427-432

63. Menser MA, Hudson JR (1983) Pancreatic islet and other autoantibodies in juvenile and adult onset diabetics in Australia. Pathology 15: 309-313

64. Notsu K, Note S, Nabeya N, Kuno S, Sakurami T (1983) Antinuclear antibodies in childhood diabetics. Endocrinol Jpn 30: 469-473

65. Huang S-W, Haedt LH, Rich S, Barbosa J (1981) Prevalence of antibodies to nucleic acids in insulin-dependent diabetics and their relatives. Diabetes $30: 873-874$

66. Banatvala JE, Schernthaner G, Schober E, De Silva LM, Bry- ant J, Borkenstein M, Brown D, Menser MA, Silink M (1985) Coxsackie B, mumps, rubella, and cytomegalovirus specific IgM responses in patients with juvenile-onset insulin-dependent diabetes mellitus in Britain, Austria, and Australia. Lancet 1: $1409-1412$

67. Frisk G, Fohlman J, Kobbah M, Ewald U, Tuvemo T, Diderholm H, Friman G (1985) High frequency of Coxsackie-B-virusspecific IgM in children developing type 1 diabetes during a period of high diabetes morbidity. J Med Virol 17:219-227

68. Wardle EN (1978) An antibody to low density lipoprotein in diabetics. Experientia 34: 886-887

69. Di Mario U, Irvine WJ, Guy K, Borsey DQ, Iavicoli M, Ventriglia L (1983) Circulating immune complexes in diabetics: the influence of sex, age, duration of disease and type of treatment. $J$ Clin Lab Immunol 11: 17-20

70. Ludwig H, Schernthaner G, Tappeiner G, Mayr WR, Freyler H (1980) Circulating immune complexes in insulin-dependent diabetes: analysis of incidence of islet cell antibodies, insulin antibodies, HLA antigens, duration of disease and stages of diabetic retinopathy. In: Autoimmune aspects of endocrine disease. Pinchera A, Doniach D, Fenzi GF, Baschieri L (eds) Acad Press, London, pp 313-318

71. Delespesse G, Gansset P, Sarfati M, Dubi-Rucquoy M, Debisschop M-J, van Haelst L (1980) Circulating immune complexes in old people and in diabetics: correlation with autoantibodies. Clin Exp Immunol 40: 96-102

72. Freedman ZR, Feek CM, Irvine WJ, Lernmark A, Rubenstein AH, Steiner DF, Huen A (1976) Islet cell cytoplasmic and cell surface antibodies in diabetes mellitus. Trans Assn Amer Phys 96: 64-76

73. Dobersen MJ, Bell AM, Jenson AB, Notkins AL, Ginsberg-Fellner F (1979) Detection of antibodies to islet cells and insulin with paraffin-embedded pancreas as antigen. Lancet 2: 1078

74. Assa S, Karp M, Erster B, Laron Z (1985) Cytoplasmic islet cell antibodies in type 1 diabetics in Israel and their first-degree relatives. Isr J Med Sci 21: 727-730

75. Marner B, Agner T, Binder C, Lernmark A, Nerup J, MandrupPoulsen T, Walldorff S (1985) Increased reduction in fasting Cpeptide is associated with islet cell antibodies in type-1 (insulindependent) diabetic patients. Diabetologia 28: 875-880

76. Borsey DQ, Di Mario U, Irvine WJ, Gray RS, Guy K, Weston J, Peutherer J, Duncan LJP (1983) Humoral immunity in type 1 diabetes mellitus: a prospective study. J Clin Lab Immunol 11:9-15

77. Gepts W (1965) Pathologic anatomy of the pancreas in juvenile diabetes mellitus. Diabetes 14: 619-633

78. Foulis AK, Stewart JA (1984) The pancreas in recent-onset type 1 (insulin-dependent) diabetes mellitus: insulin content of islets, insulitis, and associated changes in the endocrine acinar tissue. Diabetologia 26: 456-461

79. Rodier M, Andary M, Richard JL, Mirouze J, Clot J (1984) Peripheral blood T-cell subsets studied by monoclonal antibodies in type 1 (insulin-dependent) diabetes: effect of blood glucose control. Diabetologia 27: 136-138

80. Herold KC, Huen A, Gould L, Traisman H, Rubenstein AH (1984) Alterations in lymphocyte subpopulations in type 1 (insulin-dependent) diabetes mellitus: exploration of possible mechanisms and relationships to autoimmune phenomena. Diabetologia 27: $102-105$

81. Mascart-Lemone F, Delespesse G, Dorchy H, Lemiere B, Servais $G$ (1982) Characterization of immunoregulatory T lymphocytes in insulin-dependent diabetic children by means of monoclonal antibodies. Clin Exp Immunol 47: 296-300

82. Galluzzo A, Giordano C, Rubino G, Bompiani GD (1984) Immunoregulatory $\mathrm{T}$-lymphocyte subset deficiency in newly diagnosed type 1 (insulin-dependent) diabetes mellitus. Diabetologia 26: 426-430

83. Buschard K, Ropke C, Madsbad S, Mehlsen J, Rygaard J (1983) Tlymphocyte subsets in patients with newly diagnosed type 1 (insulin-dependent) diabetes: a prospective study. Diabetologia $25: 247-251$ 
84. Horita M, Suzuki H, Onodera T, Ginsberg-Fellner F, Fauci AS, Notkins AL (1982) Abnormalities of immunoregulatory T cell subsets in patients with insulin-dependent diabetes mellitus. J Immunol 129: 1426-1429

85. Hayward AR, Herberger M (1984) Culture and phenotype of activated T-cells from patients with type-1 diabetes mellitus. Diabetes 33: 319-323

86. Jackson RA, Morris MA, Haynes BF, Eisenbarth GS (1982) Increased circulating Ia-antigen-bearing $T$ cells in type 1 diabetes mellitus. N Engl J Med 306: 785-788

87. Ilonen J, Surcel H-M, Mustonen A, Kaar M-L, Akerblom HK (1984) Lymphocyte subpopulations at the onset of type-1 (insulin-dependent) diabetes. Diabetologia 27: 106-108

88. Chandy KG, Charles MA, Buckingham B, Waldeck N, Kershnar A, GuptaS (1984) Deficiency of monoclonal antibody (Leu 7) defined NK cells in newly diagnosed insulin-dependent diabetes mellitus. Immunol Lett 8: 89-91

89. Alviggi L, Hoskins PJ, Pyke DA, Johnston C, Tee DEH, Leslie RDG, Vergani D (1984) Pathogenesis of insulin-dependent diabetes: a role for activated T lymphocytes. Lancet $2: 4-6$

90. Zier KS, Leo MM, Spielman RS, Baker L (1984) Decreased synthesis of interleukin-2 (IL-2) in insulin-dependent diabetes mellitus. Diabetes 33: 552-555

91. Nerup J, Andersen OO, Bendixen G, Egeberg J, Poulsen JE (1973) Antipancreatic, cellular hypersensitivity in diabetes mellitus: antigenic activity of fetal calf pancreas and correlation with clinical type of diabetes. Acta Allergol 28: 223-230

92. MacCuish AC, Jordan J, Campbell CJ, Duncan LJP, Irvine WJ (1974) Cell-mediated immunity to human pancreas in diabetes mellitus. Diabetes 23: 693-697

93. Topliss D, How J, Lewis M, Row V, Volpe R (1983) Evidence for cell-mediated immunity and specific suppressor Tlymphocyte dysfunction in Graves' disease and diabetes mellitus. J Clin Endocrinol Metab 57: 700-705

94. Mori Y, Matsuda I, Tsuruoka A, Sasaki A, Utsunomiya K Ishii K, Yamada H, Tanese T, Ishikawa H, Suko M, Shida T, Ikeda $Y$ (1985) Cellular hypersensitivity to human pancreatic B-cell clone in diabetes mellitus and its relationship to the presence of islet cell antibodies. Endocrinol Jpn 32: 497-504

95. Gupta S, Fikrig S, Orti E (1983) Autologous mixed lymphocyte reaction in man VI. Deficiency of autologous mixed lymphocyte reaction in type 1 (insulin-dependent) diabetes mellitus. J Clin Lab Immunol 11: 59-62

96. Delespesse G, Duchateau J, Bastenie PA, Lauvaux JP, Collet H, Govaerts A (1974) Cell-mediated immunity in diabetes mellitus. Clin Exp Immunol 18: 461-467

97. MacCuish AC, Jordan J, Campbell CJ, Duncan LJP, Irvine WJ (1975) Cell-mediated immunity in diabetes mellitus. Lymphocyte transformation by insulin and insulin fragments in insulin-treated and newly-diagnosed diabetics. Diabetes $24: 36-43$

98. Nell L, Thomas JW (1983) The human immune response to insulin. I. Kinetic and cellular aspects of lymphocyte proliferative responses in diabetics. J Immunol 131: 701-705

99. Kurtz AB, Di Silvio L, Lydyard P (1985) Lymphocyte proliferation as a test of the immune response to insulin in diabetics. Diabetes Res 2: 175-178

100. Bagdade JD, Nielson KL, Bulger RJ (1972) Reversible abnormalities in phagocytic function in poorly controlled diabetic patients. Am J Med Sci 263: 451-456

101. Berken A, Sherman AA (1974) Reticuloendothelial system phagocytosis in diabetes mellitus. Diabetes $23: 218-220$

102. Pozzilli P, Gorsuch A, Sensi M. Bottazzo GF, Cudworth AG (1979) Evidence for raised K-cell levels in type-1 diabetes. Lancet 2: 173-175

103. Charles MA, Suzuki M, Waldeck N, Dodson LE, Slater L, Ong K, Kershnar A, Buckingham B, Golden M (1983) Immune islet killing mechanisms associated with insulin-dependent diabetes: in vitro expression of cellular and antibody-mediated islet cell cytotoxicity in humans. J Immunol 130: 1189-1194
104. Huang S-W, Maclaren NK (1976) Insulin-dependent diabetes: a disease of autoaggression. Science 192: 64-66

105. Selam JL, Clot J, Andary M, Mirouze J (1979) Circulating lymphocyte subpopulations in juvenile insulin-dependent diabetes: correction of abnormalities by adequate blood glucose control. Diabetologia 16: 35-40

106. Cacciari E, Masi M, Franceschi C, Cicognani A, Pirazzoli P, Licastro F, Fantini MP, Chiricolo M, Tassinari D (1980) Immunological abnormalities in juvenile onset diabetes. In: Autoimmune aspects of endocrine disease. Pinchera A, Doniach D, Fenzi GF, Baschieri L (eds) Acad Press, London, pp 329-332

107. Plouffe JF, Silva J Jr, Fekety R, Allen JL (1978) Cell-mediated immunity in diabetes mellitus. Infect Immun 21: 425-429

108. Lederman MM, Ellner JJ, Rodman HM (1981) Defective suppressor cell generation in juvenile onset diabetes. $\mathbf{J}$ Immunol 127: 2051-2055

109. MacCuish AC, Urbaniak SJ, Campbell CJ, Duncan LJP, Irvine WJ (1974) Phytohemagglutinin transformation and circulating lymphocyte subpopulations in insulin-dependent diabetic patients. Diabetes 23: 708-712

110. Fairchild RS, Kyner JL, Abdou NI (1982) Specific immunoregulation abnormality in insulin-dependent diabetes mellitus. J Lab Clin Med 99: 175-186

111. Jaworski MA, Colle E, Guttmann RD (1983) Abnormal immunoregulation in patients with insulin dependent diabetes mellitus and their healthy first degree relatives. Hum Immunol 7:25-34

112. Buschard K, Madsbad S (1984) A longitudinal study of virus antibodies in patients with newly diagnosed type 1 (insulin dependent) diabetes mellitus. J Clin Lab Immunol 13: 65-70

113. Buschard K, Madsbad S, Rygaard J (1980) Depressed suppressor cell activity in patients with newly diagnosed insulin-dependent diabetes mellitus. Clin Exp Immunol 41:25-32

114. Rerup CC (1970) Drugs producing diabetes through damage of the insulin secreting cells. Pharmacol Rev 22: 485-518

115. Cooperstein SJ, Watkins D (1981) Action of toxic drugs on islet cells. In: The islets of Langerhans. Cooperstein SJ, Watkins D (eds) Academic Press, New York, pp 387-425

116. Naji A, Barker CF (1984) Animal models of human type 1 diabetes. In: Immunology of clinical and experimental diabetes. Gupta S (ed) Plenum, New York, pp 91-112

117. Boitard C, Debray-Sachs M, Bach JF (1986) Autoimmune disorders in diabetes. Adv Nephrol 15:281-305

118. Pasko KL, Salvin SB, Winkelstein A (1981) Mechanisms in the in vivo release of lymphokines. V. Responses in alloxan-treated and genetically diabetic mice. Cell Immunol 62: 205-219

119. Pavelic K, Slijepcevic M, Pavelic J (1978) Recovery of immune system in diabetic mice after treatment with insulin. Horm Metab Res 10:381-386

120. Ptak W, Czarnik Z, Hanczakowska M (1975) Contact sensitivity in alloxan-diabetic mice. Clin Exp Immunol 19: 319-325

121. Roth MD, Barg M, Michalski R, Arquilla ER (1980) Cell-mediated immunity in chronically diabetic mice. Diabetes 29: 825-829

122. Mahmoud AAF, Rodman HM, Mandel MA, Warren KS (1976) Induced and spontaneous diabetes mellitus and suppression of cell-mediated immunologic responses. Granuloma formation, delayed dermal reactivity, and allograft rejection. J Clin Invest 57:362-367

123. Ptak W, Hanczakowska M, Rozycka R, Rozycka D (1977) Impaired antibody responses in alloxan diabetic mice. Clin Exp Immun 29: 140-146

124. Gaulton GN, Schwartz JL, Eardley DD (1985) Assessment of the diabetogenic drugs alloxan and streptozotocin as models for the study of immune defects in diabetic mice. Diabetologia 28: 769-775

125. Drachman RH, Root RK, Wood WB Jr (1966) Studies on the effect of experimental nonketotic diabetes mellitus on antibacterial defense. I. Demonstration of a defect in phagocytosis. J Exp Med 124: $227-240$

126. Weir DM, Blackwell CC, McLean CA (1981) Impaired bacterial 
binding to peritoneal exudate cells from mice with alloxan induced diabetes. J Clin Lab Immunol 5: 37-40

127. Pallavicini MG, Nichols WK (1976) Inhibition of lymphocyte blastogenesis by factor(s) in alloxan-diabetic rat plasma. Diabetes 25:614-622

128. Nevalainen DE, Hoftiezer V (1977) The response of C3H mice to streptozotocin. I. Thymic depression and leukocyte toxicity. Am J Med Technol 43: 417-418

129. Nichols WK, Spellman JB, Vann LL, Daynes RA (1979) Immune responses of diabetic animals: direct immunosuppressant effects of streptozotocin in mice. Diabetologia 16:51-57

130. Nichols WK, Vann LL, Spellman JB (1981) Streptozotocin effects on Tlymphocytes and bone marrow cells. Clin Exp Immunol 46: $627-632$

131. Ishabashi T, Kitahara Y Harada Y, Harada S, Takamoto M, Ishibashi T (1980) Immunologic features of mice with streptozotocin-induced diabetes. Depression of their immune responses to sheep red blood cells. Diabetes 29: 516-523

132. Chi DS, Berry DL, Dillon KA, Arbogast BW (1982) Inhibition of in vitro lymphocyte response by streptozotocin-induced diabetic rat serum: a function of very-low-density lipoproteins. Diabetes 31: 1098-1104

133. Saiki O, Negoro S, Tsuyuguchi I, Yamamura Y (1980) Depressed immunological defense mechanisms in mice with experimentally induced diabetes. Infect Immun 28: 127-131

134. Handwerger BS, Fernandes G, Riehm T, Sutherland DER, Brown DM (1984) Alterations in immunological function in streptozotocin-induced murine diabetes mellitus: correction by islet cell transplantation. Clin Immunol Immunopathol 32: 275-284

135. Kitahara Y, Ishibashi $T$, Harada $Y$, Takamoto $M$, Tanaka $K$ (1981) Reduced resistance to Pseudomonas septicaemia in diabetic mice. Clin Exp Immunol 43: 590-598

136. Rhodes J (1975) Modulation of macrophage Fc receptor expression in vitro by insulin and cyclic nucleotides. Nature 257: 597-599

137. Lima AO, Queiroz M, Brascher HM, Vargens J (1979) Effect of insulin on immunological phagocytosis by macrophages. Experientia 35: 119-120

138. Kragballe K, Beck-Nielsen H, Pedersen O, Ellegaard J, Sorensen NS (1981) Monocyte-mediated antibody-dependent cytoxicity. Modulation by glycolysis and insulin. Scan J Haematol 26: 137-144

139. Bar RS, Kahn CR, Koren HS (1977) Insulin inhibition of antibody-dependent cytotoxicity and insulin receptors in macrophages. Nature 265: 632-634

140. Snow EC, Feldbush TL, Oaks JA (1980) The role of insulin in the response of murine $T$ lymphocytes to mitogenic stimulation in vitro. J Immunol 124: 739-744

141. Kumagai J-I, Akiyama H, Iwashita S, Iida H, Yahara I (1981) In vitro regeneration of resting lymphocytes from stimulated lymphocytes and its inhibition by insulin. J Immunol 126:1249-1254

142. Helderman JH (1981) Role of insulin in the intermediary metabolism of the activated thymic-derived lymphocyte. $J$ Clin Invest 67: 1636-1642

143. Diaz-Espada F, Lopez-Alarcon L (1982) Mitogen-induced changes in glycolytic enzymes of mouse lymphocytes: influence of insulin on cell activation in vitro. Immunology 46: 705-712

144. Strom TB, Bangs JD (1982) Human serum-free mixed lymphocyte response: the stereospecific effect of insulin and its potentiation by transferrin. J Immunol 128: 1555-1559

145. Snow EC, Feldbush TL, Oaks JA (1981) The effect of growth hormone and insulin upon MLC responses and the generation of cytotoxic lymphocytes. J Immunol 126: 161-164
146. Strom TB, Bear RA, Carpenter CB (1975) Insulin-induced augmentation of lymphocyte-mediated cytotoxicity. Science 187: 1206-1208

147. Helderman JH, Strom TB (1977) Emergence of insulin receptors upon alloimmune $T$ cells in the rat. J Clin Invest 59:338-344

148. Hunt P, Eardley DD (1986) Suppressive effects of insulin and insulin-like growth factor-1 (IGF1) on immune responses. J Immunol 136: 3994-3999

149. Krug U, Krug F, Cuatrecasas P (1972) Emergence of insulin receptors on human lymphocytes during in vitro transformation. Proc Natl Acad Sci USA 69:2604-2608

150. Helderman JH, Strom TB (1979) Role of protein and RNA synthesis in the development of insulin binding sites on activated thymus-derived lymphocytes. J Biol Chem 254: 7203-7207

151. Hadden JW, Hadden EM, Wilson EE, Good RA, Coffey RG (1972) Direct action of insulin on plasma membrane ATPase activity in human lymphocytes. Nature New Biol 235: 174-177

152. Pavelic K, Vuk-Pavelic S (1981) Retarded growth of murine tumors in vivo by insulin- and glucagon-stimulated immunity and phagocytosis. J Nat Cancer Inst 66: 889-892

153. Bhakri HL, Jones H, Jones DA, Pettingale KW, Tee DEH (1983) T cell subpopulation dynamics following insulin-induced hypoglycemia in normal subjects. Clin Exp Immunol 53: 83-87

154. Notkins AL, Prabhakar BS (1986) Monoclonal autoantibodies that react with multiple organs: basis for reactivity. In: Autoimmunity, experimental and clinical aspects. Schwartz RS, Rose NR (eds) Ann NY Acad Sci 475: 123-124

155. Volpe R (1985) Autoimmune thyroid disease. In: Autoimmunity and endocrine disease. Volpe R (ed) Marcel Dekker, New York, pp 109-285

156. Shoenfeld Y, Schwartz RS (1984) Immunologic and genetic factors in autoimmune diseases. N Engl J Med 311: 1019-1029

157. Oldstone MBA, Notkins AL (1986) Molecular mimicry. In: Notkins AL, Oldstone MBA (eds) Concepts in viral pathogenesis II. Springer, New York, pp 195-202

158. Witzum JL, Steinbrecher UP, Kesaniemi YA, Fisher M (1984) Autoantibodies to glucosylated proteins in the plasma of patients with diabetes mellitus. Proc Natl Acad Sci USA 81:3204-3208

159. Cohen MP (1986) Diabetes and Protein Glycosylation. Measurement and Biologic Relevance. Springer, New York, pp 1-168

160. Rimoin DL, Rotter II (1984) The genetics of diabetes mellitus. In: Immunology in diabetes. Andreani D, DiMario U, Federlin KF, Heding LG (eds) Kimpton, London, pp 45-62

161. Dausset J, Hors J (1984) Immunogenetics of insulin-dependent juvenile diabetes. Diabetes Res 1: 115-123

162. Baker L, Kaye R, Root AW (1967) The early partial remission of juvenile diabetes mellitus. The roles of insulin and growth hormone. J Pediatr 71: 825-831

163. Hosker JP, Turner RC (1982) Insulin treatment of newly-presenting ketotic diabetic patients into the honeymoon period. Lancet 2: 633-635

164. Johansen $\mathrm{K}$, Orskov $H$ (1969) Plasma insulin during remission in juvenile diabetes mellitus. Br Med J 1: 676-678

Received: 20 January 1987

Dr. Abner Louis Notkins

National Institute of Dental Research

National Institutes of Health

Building 30, Room 121

Bethesda, Maryland 20892

USA 